\title{
Ecology of a relict population of the vulnerable butterfly Pyrgus sidae on the Iberian Peninsula (Lepidoptera: Hesperiidae)
}

\author{
JuAN L. HERNÁNDEZ-ROLDÁN, Miguel L. MUNGUIRA and JosÉ MARTÍN
}

\begin{abstract}
Departamento de Biología (Zoología), Universidad Autónoma de Madrid, C/ Darwin, 2, ES-28049 Madrid, Spain;
\end{abstract} e-mails: hernandez.roldan@gmail.com; munguira@uam.es; jose.martin.cano@uam.es

Key words. Conservation, Hesperiidae, Lepidoptera, mark-release-recapture, population parameters, Pyrgus sidae, relict population, resource use, spatial distribution, Iberian Peninsula, Potentilla recta

\begin{abstract}
There are isolated populations of the endangered butterfly, Pyrgus sidae, on the Iberian Peninsula. The mark-releaserecapture method was used to study the population parameters, the use of resources and the spatial distribution of a population in the centre of Spain. The estimated number of males and females within the population were similar and did not differ significantly from a ratio of $1: 1$. Total population size was estimated to be $569 \pm 83$ individuals. Potentilla recta is the principal adult nectar source and larval food plant, and its abundance is correlated with the number of marked and recaptured butterflies. The average total distance moved between capture and recapture was significantly greater for males than females, but the average daily distances moved were similar for both sexes. The spatial distribution of the movements of males and females was of a uniform type and lacked a predominant flight direction, which is typical of sedentary species. Continuing the traditional land use (cattle grazing or hay mowing) of the habitat of the species keeps the habitat open, which is necessary if the butterfly is to survive at this locality. These management practices favour $P$. recta, which would otherwise succumb to competition from invasive shrubs. Taking into account the habitat requirements of this species, it is important to conserve the mosaic of meadows already present in the area.
\end{abstract}

\section{INTRODUCTION}

A knowledge of the factors that cause changes in populations of butterflies living in small and isolated populations is crucial for developing conservation programs (Thomas, 1991). The study of population parameters and their response to changes in the environment provide relevant tools for classifying endangered species and designing suitable conservation strategies (IUCN, 2001).

A good example of a species with isolated and endangered populations is the butterfly Pyrgus sidae (Esper, 1782) on the Iberian Peninsula. This species is listed in the Spanish Invertebrate Red Data Book (Verdú \& Galante, 2006) as a vulnerable species, due to its restricted range and the isolation of the relic Iberian populations (see below) from the species' main range (Martín et al., 2006). The closest populations are on the other side of the Pyrenees in SE France, more than $1000 \mathrm{~km}$ away. According to Jong (1972), the French and Italian distribution resulted from a postglacial expansion from a refuge in the Italian Peninsula. The Iberian populations presumably originated from another glacial refuge, which increases the urgency of their conservation, because they are likely to be genetically different and therefore relevant to the conservation of the species' genetic diversity.

Population studies of endangered butterflies have received considerable attention (e.g. Pfeifer et al., 2000, Arnyas et al., 2005; Nowicki et al., 2005a). The skippers (Hesperiidae family) represent an under-studied group within butterflies, although some population ecology studies exist, e.g., for Carterocephalus palaemon (Ravenscroft, 1994a, b), Hesperia comma (Hill et al., 1996;
Davies et al., 2005), Erynnis tages (Gutierrez et al., 1999) and Pyrgus armoricanus (Öckinger, 2006).

We used the mark-release-recapture (MRR) method in this study, which is time consuming but provides numerical information on several relevant population demographic parameters. It also provides an opportunity to study behavioural aspects and the use of space and resources (Warren, 1992; Munguira et al., 1997; Nowicki et al., 2005a).

The present paper attempts to determine whether information on several population traits of Pyrgus sidae can be used in the conservation of this rare and endangered species. The objectives were: (i) obtain numerical data (population size, sex ratio, survival, residence time and adult movements) on a relict Iberian population of the butterfly Pyrgus sidae, (ii) study the behaviour and habitat use of adult butterflies, (iii) obtain basic information on the inmature stages of the butterfly and (iv) consider the implications of the results for the conservation of the species on the Iberian Peninsula.

\section{MATERIAL AND METHODS}

\section{Study species}

The butterfly Pyrgus sidae (Lepidoptera: Hesperiidae: Pyrginae) was originally described from the Volga Region of Russia. This species, in contrast to other species of the genus Pyrgus Hübner, 1819, whose genitalia need to be examined for identification, is easily recognized by the vivid orange-yellow bands on the underside of the hindwings.

$P$. sidae has a South-Palaearctic distribution ranging from Spain, France and Italy towards Turkistan, with populations in Hungary and Turkey (Warren, 1926; Jong, 1972; Kudrna, 2002; García-Barros et al., 2004). In Spain, it was discovered as late as 

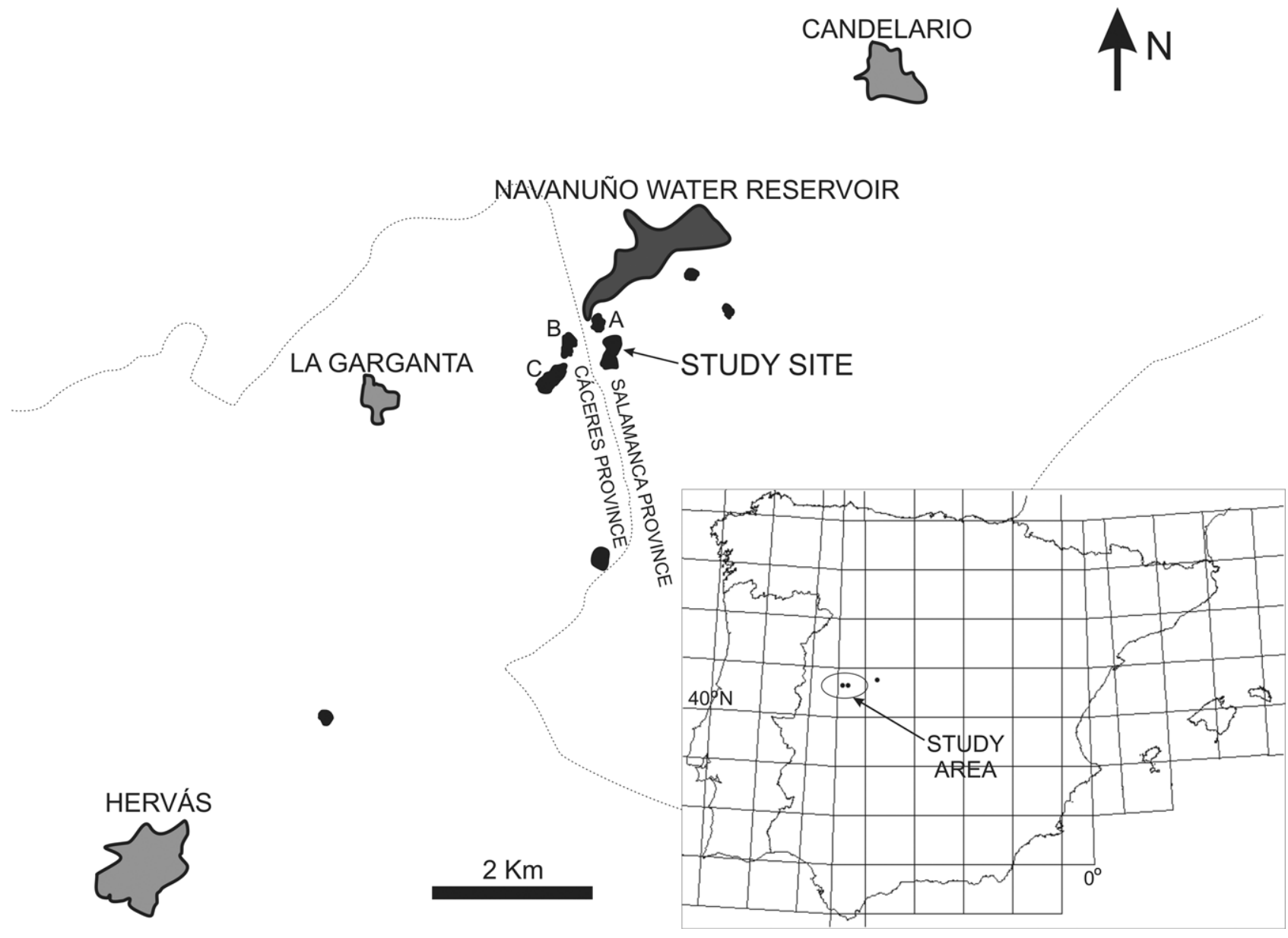

Fig. 1. Geographic distribution of Pyrgus sidae on the Iberian Peninsula mapped in U.T.M $10 \times 10 \mathrm{~km}$ squares and a detailed map of all known populations in the study area. The villages are represented in light grey, the water reservoir in dark grey and the black patches are the areas where Pyrgus sidae was recorded regularly. The main study area is indicated along with patches A, B and C where transect counts were made to detect movements outside the study site.

1985 (Martínez \& Sánchez, 1987) and is only recorded in three $10 \times 10 \mathrm{~km}$ UTM squares in the centre of the Iberian Peninsula (Fig. 1). All populations are found within a $30 \mathrm{~km}^{2}$ strip of land between the towns of Hervás (Cáceres Province) and Candelario (Salamanca Province), plus a single record from the Sierra de Gredos (Avila Province) (Blázquez et al., 2003; García-Barros et al., 2004). The very restricted geographic distribution makes this butterfly one of the rarest on the Iberian Peninsula (GarcíaBarros et al., 2004).

The species is univoltine and overwinters as a third or fourth instar larva. The adults fly from May to July. The larval foodplants are Potentilla hirta L. (Rosaceae) in southeast France (Powell, 1911; Nel, 1984, 1985), P. recta L. in Greece and Spain (Tolman \& Lewington, 1997; Blázquez et al., 2003; Vicente \& Hernández-Roldán, 2007) and Abutilon avicennae Gaertn. (Malvaceae) in the orient (Guillaumin, 1964; Nel, 1984).

\section{Study area}

The known Pyrgus sidae populations on the Iberian Peninsula are patchily distributed (Fig. 1), with all the known sites covering a total area of ca 25 ha. In the area there are other potentially suitable sites that appear to be unoccupied by this species. The distances between the occupied patches range from 0.5 to 7 $\mathrm{km}$.

We carried out the study in the Candelario Nature Reserve (Espacio Natural de Candelario), Province of Salamanca (W
Iberian Peninsula) (Fig. 1). The area has a mountain climate, with long cold winters and short cool summers.

A preliminary study indicated that the patch selected for this study contained the highest population density of $P$. sidae in the area and thus harboured the most important population on the Iberian Peninsula. It was a 4.9 ha patch of grassland alternatively grazed by cattle and used as hay meadows. The altitudes range from 1300 to $1375 \mathrm{~m}$. It was completely surrounded by pine plantations (Pinus sylvestris L.) except for its northern limit, where the plantation was dissected by a local metalled road. The natural vegetation in the area is a supramediterranean formation dominated by Pyrenean oak, Quercus pyrenaica Willd. (Leuzeo-Quercetum pyrenaicae vegetation: RivasMartinez, 1987). The oak forests were cleared to provide space for traditional grazed grasslands and some areas were planted with pine forests.

\section{Mark-release-recapture (MRR) study}

For the mark-release-recapture (MRR), we divided the patch into 22 arbitrary plots that varied in size (1364 to $\left.3402 \mathrm{~m}^{2}\right)$ but were easily identifiable by landmarks (prominent trees, rocks or water courses).

We marked the butterflies from 8 June to 2 July 2005, within the usual flight period of the species. However in 2005 the adults emerged significantly earlier and butterflies at the beginning of the flight season were not marked. There were eight sampling events spaced at intervals of three to four days. On 
TABle 1. Population parameter estimates for a Pyrgus sidae population in Central Western Spain based on a Mark-ReleaseRecapture study. The selected model was $P h i$ (.) $P(g) P e n t(g) N(g)$. $P h i=$ apparent survival, $P=$ capture probability, $P e n t=$ probability of entry, $N=$ seasonal population size, $\mathrm{CI}=$ confidence interval.

\begin{tabular}{cccccc}
\hline Parameter & Sex & Estimate & Standard Error & 95\% CI Lower & 95\% CI Upper \\
\hline Phi $()$. & & 0.90 & 0.01 & 0.87 & 0.92 \\
$P(g)$ & Males & 0.39 & 0.05 & 0.30 & 0.49 \\
$P(g)$ & Females & 0.15 & 0.04 & 0.09 & 0.25 \\
Pent $(g)$ & Males & 0.07 & 0.01 & 0.05 & 0.09 \\
Pent $(g)$ & Females & 0.12 & 0.01 & 0.10 & 0.14 \\
$N(g)$ & Males & 291.8 & 20.2 & 252.3 & 331.3 \\
$N(g)$ & Females & 277.1 & 63.7 & 152.2 & 402.1 \\
\hline
\end{tabular}

each sampling day every plot of the study site was walked through twice (Munguira et al., 1997). The first walk lasted from 11:00-13:30 $\mathrm{h}$, the second from 15:00-17:30 h local time. Climatic conditions were always favourable: temperature > $19^{\circ} \mathrm{C}$, no strong winds, cloud cover $<20 \%$.

All the butterflies seen were captured with a net, marked on the wings using waterproof pens (Munguira et al., 1997) and immediately released. The following data were recorded for each captured or recaptured individual: plot number, sex and behaviour (flying, feeding, basking, ovipositing, courting or mating). Behavioural patterns are relevant as they indicate how adults use the space in the habitat (Munguira \& Thomas, 1992). In the case of feeding, the plant species used as the nectar source was also recorded.

To detect long-distance movements originating from the studied population, we walked linear transects through other closely-situated occupied patches but did not mark the butterflies. This started in the second sampling session and was of patches within a $1.5 \mathrm{~km}$ radius (patches $\mathrm{A}, \mathrm{B}, \mathrm{C}$ with areas of 2.1, 3.5 and 5.2 ha respectively; Fig. 1) of the study site. Whenever a previously marked individual was captured, its identification details were recorded. We also recorded total numbers of individuals observed.

The density of the larval food plant was estimated by counting the number of $P$. recta plants per plot. The correlation between butterfly abundance and food plant density was determined for each plot. Once the butterfly flight period was over, the site was visited (13th August, 2005) to record land use. On 14th May, 2006 a further visit was made to check the management and search for last instar larvae.

\section{Data analysis}

Capture-recapture data were analysed according to the models of Cormarck-Jolly-Seber (CJS: Schwarz \& Arnason, 1996; Schwarz \& Seber, 1999) using the program MARK 2.1 (White \& Burnham, 1999). Residence time was estimated following Cook et al. (1967).

To test the statistical quality of the fit of the data (GOF) to CJS models a variance inflation factor was used $(\hat{C}$ : McDonald et al., 2005). This was estimated using the results from Test 2 and Test 3 in the program RELEASE (Burnham et al., 1987), which is part of MARK 2.1 software. To select the model that best fitted the data, the model with the lower corrected Akaike's information criterion was used ( $\mathrm{AIC}_{\mathrm{C}}$ : Hurvich \& Tsai, 1989).

The sex ratio on every sampling day is defined as the ratio of the number of estimated males on that day and the total number of estimated butterflies. To test if the total number of males and females fitted the expected $1: 1$ ratio, a chi-square test was performed. Adult mobility was estimated by measuring and summing the distances between the centres of consecutive capture points. When capture and recapture took place in the same plot the distance was regarded as zero. A two-dimensional vectorial data analysis of the direction of the movements was performed, independently for each sex, using the Rayleigh's parametric test of uniformity, from which equal-area circular histograms (rose diagrams) were built with program EZ-ROSE 1.0 (Baas, 2000).

In each plot within the study site, the correlation between the following parameters was computed: marked males, marked females, total marked specimens, recaptured butterflies, plot area and Potentilla recta density. First, we determined if the parameters were normally distributed using the KolmogorovSmirnov test.

\section{Life history}

The life cycle of Pyrgus sidae in the population studied was followed by collecting a small sample of eggs from the larval food plant during the MRR study. Immature stages were reared in captivity outdoors, at an altitude of $350 \mathrm{~m}$ and fed Potentilla recta plants growing in flower-pots. The exact position on plants where we found the eggs and larvae were recorded, as this information is needed for developing suitable management regimes for the conservation of this species.

\section{RESULTS}

\section{Population parameters}

We marked a total of 244 individuals: 171 males and 73 females. 101 of the captures $(41.4 \%)$ were previously marked: 69 of these butterflies were recaptured once, 24 twice and 8 three times. The recaptures were of males in 85 cases $(49.7 \%$ of the total number of males marked) and females in 16 (21.9\% of the females marked).

The GOF test showed a good fit of the data to the CJS model $(\hat{C}=0.8)$. The model selection procedure indicated

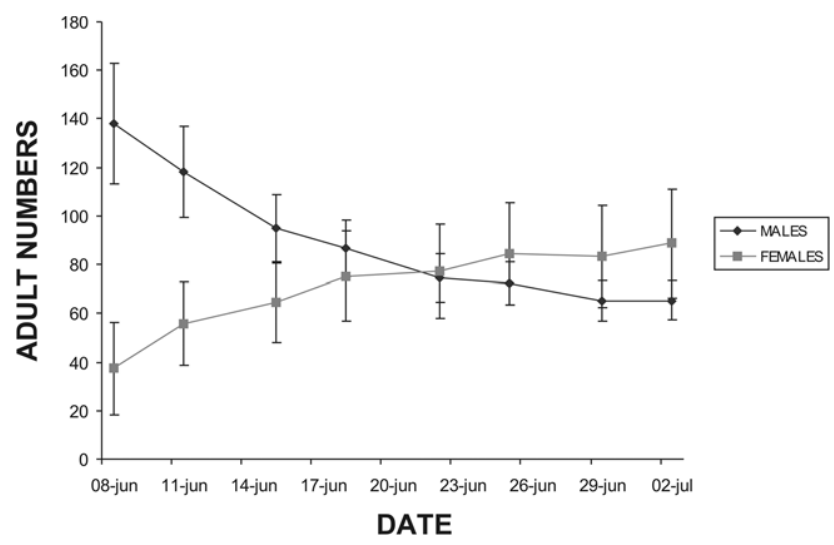

Fig. 2. Changes in the estimates of the numbers of males and females present at different times in a Pyrgus sidae butterfly population in Central Western Spain. The Program MARK and model $P h i$ (.) $P(g)$, of the results of the mark-release-recapture study in 2005 were used. $\left(N_{i}\right)$ with a $95 \%$ confidence interval. 


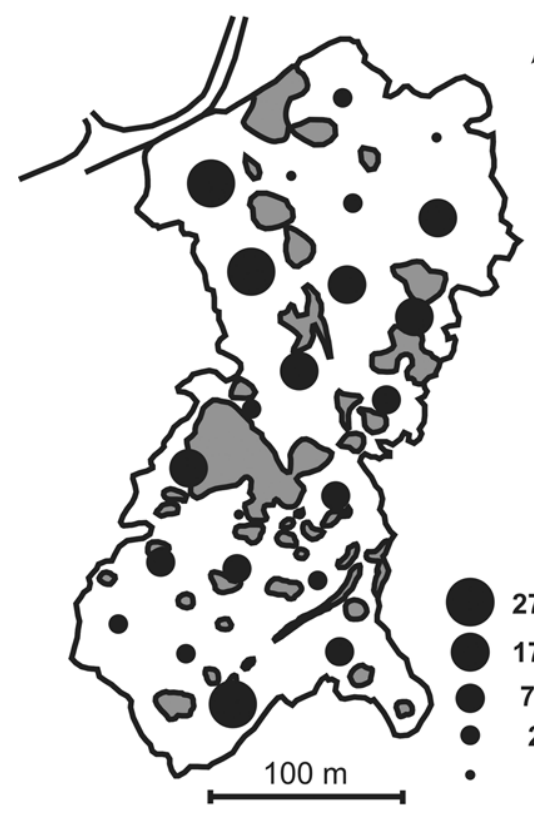

CAPTURES

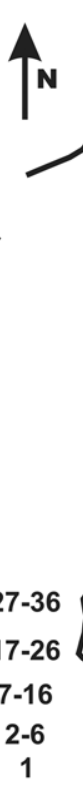

RECAPTURES

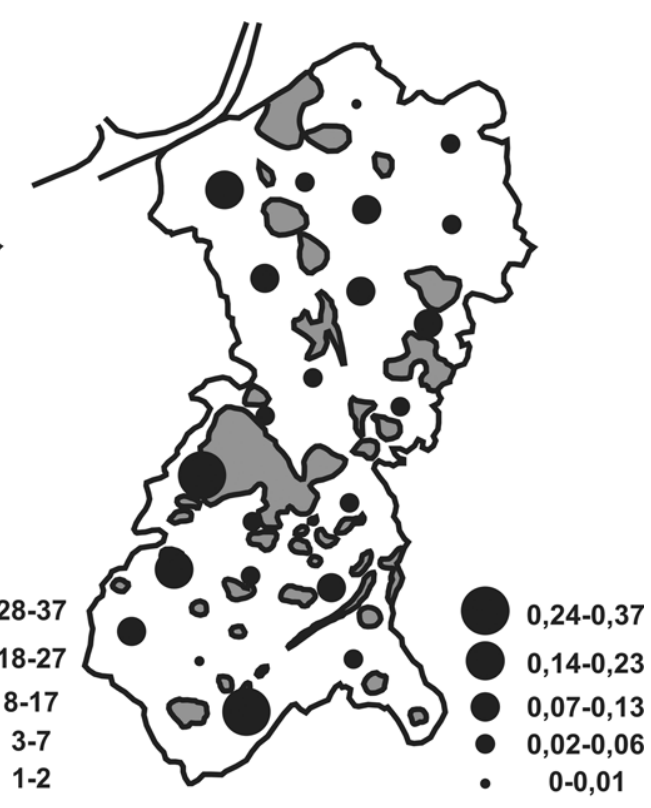

PLANTS $/ M^{2}$

Fig. 3. Distribution in each plot of the study site of the number of captures $(N=244)$ and recaptures $(N=252)$ recorded in a MRR study of a Pyrgus sidae butterfly population in Central Western Spain. The density (plants $/ \mathrm{m}^{2}$ ) of Potentilla recta, the larval food plant, in each patch is also shown. Shaded areas were covered by trees and the rest of the area consists of meadows.

that model Phi (.) $P(g)$ Pent ( $g$ ) $N(g)$ best fitted the data. In this model, the apparent survival $(P h i)$ is constant and equal for both sexes, whereas capture probability $(P)$, probability of entry (Pent) and seasonal population size (N) differ between sexes (Table 1).

Total population size was estimated to be $569 \pm 83$ individuals (a 95\% confidence interval), with a peak emergence of adults of 175 butterflies. The resulting population density at the study site was $116 \pm 17$ butterflies per ha. Estimated sex ratio did not differ significantly from the expected $1: 1$ ratio $\left(X^{2}=0.395, P>0.05\right)$. Fig. 2 shows the variation in estimated adult numbers through time. The species is protandric, with males emerging earlier than females.

The transects walked in patches close to the study site gave maximum observed estimates of 17 individuals in patch A (250 m, 11 June), 7 in patch B (350 m, 11 June) and 5 in patch $\mathrm{C}(500 \mathrm{~m}, 14$ June).

\section{Adult behaviour and use of space}

The adult behaviour of every captured and recaptured individual indicate that $61.7 \%$ were flying, $21.3 \%$ feeding, $12.4 \%$ basking, $3.2 \%$ ovipositing, $1.0 \%$ courting and $0.4 \%$ mating. Male sexual behaviour can be classified as patrolling (Scott, 1974), with males flying through the habitat in search of mates. Females lay eggs singly on the carpels of the flower of Potentilla recta and then fly to another plant (16 observations). The observed nectar sources were: $58.5 \%$ P. recta (also the larval foodplant), 20.8\% Trifolium pratensis, 17\% Taraxacum sp., 1.9\% Lotus corniculatus, $0.9 \%$ Jasione montana and $0.9 \%$ Anthemis arvensis.

The spatial distribution of captured and recaptured butterflies in each plot of the study site is shown in Fig. 3, together with the population density of the food plant $(P$. recta). Kolmogorov-Smirnov test indicated that all the variables are normally distributed. The number of marked males and females per plot was correlated $(R=0.80, N=$ $22, P<0.001)$, indicating that the sexes used space in a similar way within the study site. Plot size did not correlate with the number of marked $(R=0.28, N=22, P>$ $0.05)$ and recaptured butterflies $(R=0.19, N=22, P>$ $0.05)$, nor with the number of $P$. recta plants $(R=0.06, N$ $=22, P>0.05)$. Thus, the spatial distribution of the butterfly and its food plant were independent of plot size. However, the abundance of $P$. recta was highly correlated with the number of marked and recaptured butterflies $(R$ $=0.72$ and $R=0.86$, respectively, $N=22, P<0.001$ ).

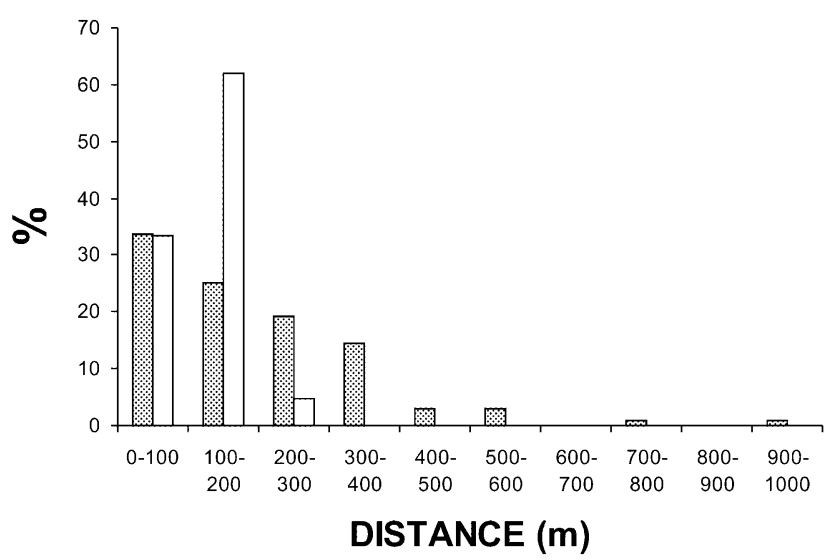

Fig. 4. Distance between points of capture and recapture and percentage of each distance class recorded for Pyrgus sidae butterflies in a MRR study in Central Western Spain. Grey bars are males $(N=104)$ and white bars females $(N=21)$. 

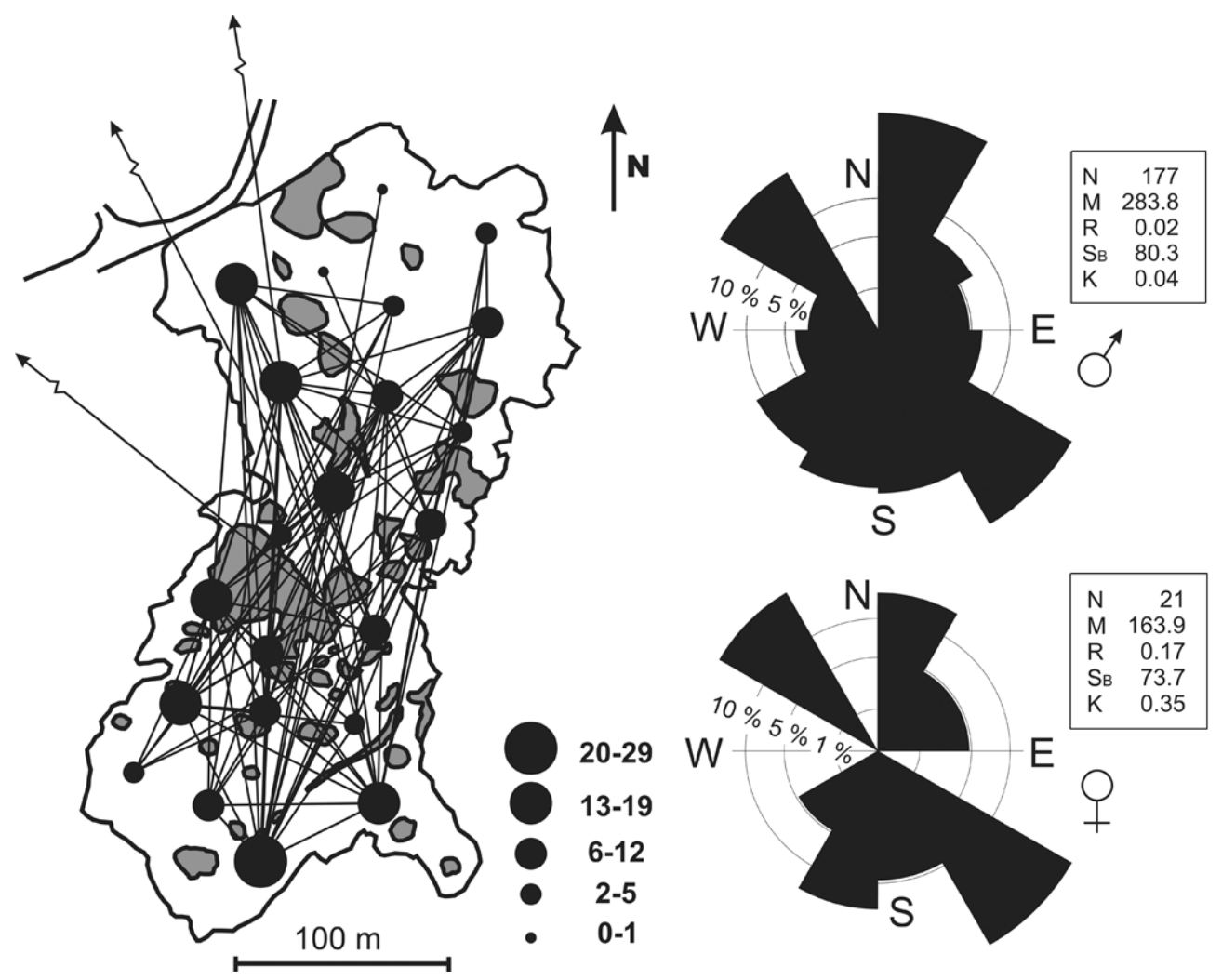

Fig. 5. Movements of Pyrgus sidae butterflies recorded in a mark-release-recapture study in Central Western Spain. Each line represents a detected movement between plots at the study site $(N=198)$. Spot size is an indication of the number of movements per plot, shaded areas were covered by trees and the rest of the area by grassland. Diagrams on the right are equal-area circular histograms (rose diagrams) of the flight direction for males and females. $N=$ number of movements, $M=$ vectorial mean direction or orientation, $R=$ mean vector magnitude (mean vector length), $S_{B}=$ Batschelet's circular standard deviation, $K=$ vectorial concentration (mean vector strength).

\section{Mobility and residence time}

198 movements of 125 individuals were recorded, $66.4 \%$ moved a total distance exceeding $100 \mathrm{~m}, 35.2 \%$ moved more than $200 \mathrm{~m}$ and $18.4 \%$ more than $300 \mathrm{~m}$ (Fig. 4). The longest detected movement was $984 \mathrm{~m}$ (between the study site and patch B). The average distance between capture and recapture was significantly greater for males than females (Table 2). Three males were recaptured in nearby populations (two in patch A and one in patch B), showing some degree of exchange between populations.

The distance travelled increases significantly with time in the case of males $(R=0.53, N=104, P<0.001)$ and the two sexes combined $(R=0.55, N=125, P<0.001)$, but not for females $(R=0.29 ; N=21 ; P>0.05)$.
Detected movements of $P$. sidae butterflies within the study site are presented in the form of circular histograms (rose diagrams) in Fig. 5. The Rayleigh test indicates a uniform distribution of movements $(\alpha=0.01)$ for both males and females. This means that there is no predominant direction in the butterfly's flight, which is typical of a sedentary butterfly species (Shreeve, 1992).

Butterfly residence time was estimated to be 9.2 days and was similar for males and females, with a maximum of 14 days (a male). The survival rate (Phi) indicates that $10 \%$ of the butterflies disappear from the population (dying or emigrating) daily (Table 1).

\section{Life history}

From the sample of eight eggs collected from Potentilla recta flowers and reared in captivity, first instar larvae

TABLE 2. Average and standard deviations of the total detected movements and daily movements (in $\mathrm{m}$ ) obtained from the markrelease-recapture study of a Pyrgus sidae population in Central Western Spain. $N=$ number of observations, Max. $=$ maximum recorded distance $(\mathrm{m})$. Averages were compared using the $t$-test.

\begin{tabular}{|c|c|c|c|c|c|}
\hline & Males & Females & $t$ & $D F$ & $P$ \\
\hline Total distance $(\mathrm{m})$ & $201.6 \pm 166.1$ & $106.0 \pm 67.7$ & 4.34 & 76 & 0.0001 \\
\hline$N$ & 104 & 21 & & & \\
\hline Max. & 984.0 & 291.0 & & & \\
\hline Daily distance (m) & $90.0 \pm 103.0$ & $91.0 \pm 56.0$ & -0.07 & 123 & 0.9420 \\
\hline$N$ & 104 & 21 & & & \\
\hline Max. & 767.0 & 192.0 & & & \\
\hline
\end{tabular}


emerged after 3-4 days. They first fed on the calyx sepals that were also used to build silk shelters. After feeding on the flowers they descend to feed on stipules and leaves. They then rest in shelters made by joining the stipules to the stalk with silk, pulling several leaves together or folding a single leaf. In 20 days, the larvae reached the third instar and then fed on the basal leaves of the plant.

During summer the larvae entered diapause inside the shelters, where they also spent the winter and resumed feeding the following spring. On 15th April, there were five larvae inside the shelters. Prior to pupation, larvae spent two to three days in the prepupal stage. Pupal stage lasted 12-15 days and emergence of adults took place between May 3 and 13 (three males and two females). The rearing conditions (lower altitude, different temperatures) resulted in a slightly earlier emergence of these butterflies than recorded in the natural habitat of the species.

On 13th August, 2005 it was noted that ten of the 22 plots within the study site had been recently grazed by cattle. Grazing cattle consume almost all the upper parts of the plants but not the basal rosettes of plants like $P$. recta. On 14th May, 2006 adults of this species were still flying and a last instar larvae was collected in a shelter at the base of a food plant. It pupated and produced an adult female on May 27th.

\section{DISCUSSION AND CONCLUSIONS}

\section{Population size of endangered species}

The Pyrgus sidae population studied consisted of $569 \pm$ 83 individuals. This is probably an underestimate, because our sampling period did not cover the entire flight period and we observed no prominent population peak (Fig. 2). Following the Davies et al. (2005) criteria, our $P$. sidae population, with an observed adult maximum of 175 butterflies, can be considered a small population (100-500 individuals at peak emergence).

Taking into account the size of this population and the total area of occupied patches (Fig. 1) the population in the whole area may be around a few thousand individuals. This falls within the range of other studies on endangered or very rare species (e.g.: Maculinea nausithous, Nowicki et al., 2005b; Euphydryas aurinia, Munguira et al., 1997). Within the Hesperiidae family, the Erynnis tages population studied by Gutierrez et al. (1999) in the UK is comparable in size to that of the Iberian $P$. sidae population. Density (116 adults/ha) is lower than typical figures obtained for other butterfly species: e.g. Maculinea species with 150-1100 adults/ha (Munguira \& Martín, 1999).

\section{Mobility and residence time}

The average daily distance moved at this study site was similar for males and females, but total distances were greater for males. Shreeve (1992) states that age and reproductive status have a significant influence on female mobility (mated females are more mobile than virgin ones). Estimated total distances covered by $P$. sidae in its lifetime are similar to those of individuals in Danish populations of $P$. armoricanus (Christensen, 2000) and almost twice those of males of Erynnis tages in the UK, but are similar for females (Gutierrez et al., 1999). The three species are rather sedentary in the populations studied, and only occasionally were movements greater than $400 \mathrm{~m}$ recorded.

Recorded movements for single individuals within the study site probably indicate that small barriers (roads, or pine plantations) between habitat patches do not block a genetic exchange among populations. However, the study site was too small for a reliable inference of the dispersal capacity of the species (Franzen \& Nilsson, 2007).

Adult residence time estimated for $P$. sidae (9.2 days) can be compared with that of other species of skippers. It is slightly longer than that estimated by Warren (1992) for Thymelicus acteon (6-7 days) or Hesperia comma (8 days) and clearly greater than the estimates for Erynnis tages published by Gutierrez et al. (1999) (3.3 days for males and 2.4 for females). For most of the butterflies for which there is data on residence times the values range from 5 to 10 days, although in some species it is only 3-4 days (Warren, 1992; Munguira et al., 1997). The rather high residence times recorded for $P$. sidae can be interpreted as a product of its low mortality rate or sedentary character (e.g. Brown \& Chippendale, 1974, state that low residence times are related to high flight activity).

\section{Conservation}

The results indicate that the abundance of Pyrgus sidae in the population studied is closely associated with the abundance of its larval food plant (butterfly abundance was highly correlated with plant abundance). Besides providing larval food, the plant is also a source of nectar (58.5\% of adult feeding records) and shelter, thus forming a critical component of the niche of $P$. sidae (cf. Gilbert \& Singer, 1975).

Maintaining traditional land use in the habitat of the species (i.e. cattle grazing alternating with hay making) is important for the conservation of this butterfly. This use of the land increases the supply of $P$. recta, which would otherwise become extinct due to succession. Grazing or mowing, when done at the end of July or in August, do not affect the survival of $P$. sidae larvae, which aestivate hidden in shelters at the bases of their host plants. This type of management, traditional in this area, does not adversely affect the other butterfly species, because most of them ( 52 species, but $P$. sidae is the only endangered one) also benefit from this type of land use. The habitat could also be improved by clear felling of trees in patches within the pine plantations in the area, so that the area of grassland is increased and a mosaic of woodland and grassland areas favourable for the food plant created (Warren, 1987).

Taking into account the population structure of the species at the study site and surrounding populations, it is important to conserve the patches of meadows of similar characteristics that are already present in the area. The survival of the species in Spain is necessarily linked to traditional grazing or mowing, which occurs after the butterfly flight period has ended. A large percentage of the species of butterfly in Europe breed in grassland habitats 
(Van Swaay \& Warren, 1999; Van Swaay, 2002). Insects have experienced higher rates of decline than other taxa in grasslands, particularly because of management changes at the edges of the species ranges (Bourn \& Thomas, 2002) like the Iberian populations of $P$. sidae.

In conclusion the $P$. sidae population studied is smaller and its population density is lower than that recorded for other endangered species. This, together with the limited number of localities on the Iberian Peninsula indicates that this species is vulnerable and sensitive to changes in traditional land use.

ACKNOWLEDGEMENTS. We would like to express our gratitude to C. Stefanescu and D. Gutiérrez for reading a previous draft of the manuscript and providing many helpful ideas. Á Blázquez helped with the drawing of some of the figures, and $\mathrm{H}$. Romo and E. García-Barros with the statistical analyses. The suggestions of M. Konvička and three anonymous reviewers considerably improved the final version of the manuscript. The Castilla y León Regional Government kindly gave us permission to sample Pyrgus sidae in the Candelario protected area.

\section{REFERENCES}

Arnyas E., Bereczki J., Toh A. \& Varga Z. 2005: Results of mark-release-recapture studies of a Maculinea rebeli population in the Aggtelek karst (N Hungary) between 2002-2004. In Settele J., Kühn E. \& Thomas J.A. (eds): Studies in the Ecology and Conservation of Butterflies in Europe. Vol. 2: Species Ecology along a European Gradient: Maculinea Butterflies as a Model. Pensoft, Sofia and Moscow, pp. 111-114.

BAAS J. 2000: EZ-ROSE: a computer program for equal-area circular histograms and statistical analysis of two-dimensional vectorial data. Comput. Geosci. 26: 153-166.

Blázquez A., Nieto M. \& Hernández-Roldán J.L. 2003: Mariposas Diurnas de la Provincia de Cáceres. Junta de Extremadura, Badajoz, $211 \mathrm{pp}$.

Bourn N.A.D. \& Thomas J.A. 2002: The challenge of conserving grasslands insects at the margins of their range in Europe. Biol. Conserv. 104: 285-292.

Brown J.J. \& Chippendale G.M. 1974: Migration of the Monarch butterfly Danaus plexippus: energy sources. J. Insect Physiol. 20: 1117-1130.

Burnham K.P., Anderson D.R., White G.C., Brownie C. \& PolLOCK K.H. 1987: Design and analysis methods for fish survival experiments based on release-recapture. Am. Fish. Soc. Monogr. 5: 1-437.

Christensen P.R. 2000: The Effects of Grazing on the Butterfly Fauna in Denmark. Ph.D. thesis, Department of Zoology, University of Aarhus, Aarhus, 112 pp.

Cook L.M., Brower L.P. \& Croze H.J. 1967: The accuracy of a population estimation from multiple recapture data. J. Anim. Ecol. 36: 57-60.

Davies Z.G., Robert J.W., Brereton T.M. \& Thomas C.D. 2005: The re-expansion and improving status of the silverspotted skipper butterfly (Hesperia comma) in Britain: a metapopulation success story. Biol. Conserv. 124: 189-198.

Franzen M. \& NiLSSON S. 2007: What is the required minimum landscape size for dispersal studies? J. Anim. Ecol. 76: $1224-1230$

García-Barros E., Munguira M.L., Martín J., Romo H., García-Pereira P. \& Maravalhas E.S. 2004: Atlas de las Mariposas Diurnas de la Península Ibérica y Baleares (Lepidoptera: Papilionoidea \& Hesperioidea). Monografías SEA 11, Zaragoza, $228 \mathrm{pp}$.
Gilbert L.E. \& Singer M.C. 1975: Butterfly ecology. Annu. Rev. Ecol. Syst. 6: 365-397.

Guillaumin M. 1964: Les espèces françaises du genre Pyrgus Hübner. Alexanor 3: 293-305.

Gutiérrez D., Thomas C.D. \& León-Cortés J.L. 1999: Dispersal, distribution, patch network and metapopulations dinamics of the dingy skipper butterfly (Erynnis tages). Oecologia 121: 506-517.

HiLl J.K., Thomas C.D. \& Lewis O.T. 1996: Effects of habitat patch size and isolation on dispersal bye Hesperia comma butterflies: implications for metapopulations structure. $J$. Anim. Ecol. 65: 725-735.

HuRvich C.M. \& Tsai C. 1989: Regression and time series model selection in small samples. Biometrika 76: 297-307.

IUCN 2001: IUCN Red List Categories and Criteria: Version 3.1. IUCN Species Survival Commission. IUCN, Gland, Switzerland and Cambridge, UK, $30 \mathrm{pp}$.

JoNG R. DE 1972: Systematics and geographic history of the genus Pyrgus in the palaearctic region. Tijdschr. Entomol. 115: $1-121$.

KudRnA O. 2002: The distribution atlas of European butterflies. Oedippus 20: 1-342.

Martín J., Munguira M.L. \& García-Barros E. 2006: Pyrgus sidae (Esper, 1782). In Verdu J.R. \& Galante E. (eds): Libro Rojo de los Invertebrados de España. Dirección General para la Biodiversidad, Ministerio de Medio Ambiente, Madrid, 223 pp.

Martínez M.A. \& SÁnchez F.J. 1987: Pyrgus sidae (Esper, 1782) nueva especie para España (Lepidoptera: Hesperiidae). SHILAP Revta. Lepid. 60: 371-375.

Mcdonald T.L., Amstrup S.C., Regehr E.V. \& Manly B.F. 2005: Examples. In Amstrup S.C., Mcdonald T.L. \& Manly B.F. (eds): Handbook of Capture-Recapture Analysis. Princeton University Press, Princeton and Oxford, pp. 196-265.

Munguira M.L. \& Martín J. 1999: Action Plan for Maculinea Butterflies in Europe, Nature and Environment No. 97. Council of Europe Publishing, Strasbourg, 64 pp.

Munguira M.L. \& Thomas J.A. 1992: Use of road verges by butterfly and burnet populations and the effect of roads on adult dispersal and mortality. J. Appl. Ecol. 29: 316-329.

Munguira M.L., Martín J., Garcia-Barros E. \& Viejo J.L. 1997: Use of space and resources in a Mediterranean population of the butterfly Euphydryas aurinia. Acta Oecol. 18: 597-612.

Nel J. 1984: Note sur Pyrgus sidae Esper: sa plante-hôte et son cycle biologique en Provence (Lep. Hesperiidae). Alexanor 13: $275-281$.

Nel J. 1985: Note sur la répartition, les plantes-hôtes et le cycle de développement des Pyrginae en Provence (Lep. Hesperiidae). Alexanor 14: 51-63.

Nowicki P., Witek M., Skórka P., Settele J. \& Woyciechowski M. 2005a: Population ecology of the endagered butterflies Maculinea teleius and M. nausithous and the implications for conservation. Popul. Ecol. 47: 193-202.

Nowicki P., Richter A., Glinka U., Holzschuh A., Toelke U., Henle K., Woyciechowski M. \& Settele J. 2005b: Less input same output: simplified approach for population size assessment in Lepidoptera. Popul. Ecol. 47: 203-212.

ÖCKINGER E. 2006: Posible metapopulation structure of the threatened butterfly Pyrgus armoricanus in Sweden. J. Insect Conserv. 10: 43-51.

Pfeifer M.A., Andrick U.R., Frey W. \& Settele J. 2000: On the ethology of a small and isolated population of the dusky large blue butterfly Glaucopsyche (Maculinea) nausithous (Lycaenidae). Nota Lepid. 23: 147-172. 
Powell H. 1911: A contribution to the life history of Hesperia sidae, Esp. Trans. Entomol. Soc. Lond. 3: 563-576.

RAVENSCROFt N.O.M. 1994a: The ecology of the chequered skipper butterfly Carterocephalus palaemon in Scotland. I. Microhabitat. J. Appl. Ecol. 31: 613-622.

RAVENSCROFT N.O.M. 1994b: The ecology of the chequered skipper butterfly Carterocephalus palaemon in Scotland. II. Foodplant quality and polpulation range. J. Appl. Ecol. 31: 623-630.

Rivas-Martínez S. 1987: Memoria del Mapa de Series de Vegetación de España. ICONA, Ministerio de Agricultura, Pesca y Alimentación, Madrid, 268 pp.

Schwarz C.J. \& ARnason A.N. 1996: A general metodology for the analysis of capture-recapture experiments in open populations. Biometrics 52: 860-873.

Schwarz C.J. \& Seber G.A.F. 1999: Estimating animal abundance: review III. Stat. Sci. 14: 427-456.

Sсотт J.A. 1974: Mate locating behavior of butterfies. Am. Midl. Nat. 91: 103-107.

Shreeve T.G. 1992: Monitoring butterfly movements. In Dennis R.L.H (ed.): The Ecology of Butterflies in Britain. Oxford University Press, Oxford, pp. 120-138.

Thomas J.A. 1991: Rare species conservation: case studies of European butterflies. In Spellerberg I.F., Goldsmith F.B. \& Morris M.G. (eds): The Scientific Management of Temperate Communities for Conservation. Blackwell Scientific Publications, Oxford, pp. 149-197.

Tolman T. \& Lewington R. 1997: Collins Field Guide Butterflies of Britain \& Europe. Harper Collins, London, 320 pp.
Van SwaAy C.A.M. 2002: The importance of calcareous grasslands for butterflies in Europe. Biol. Conserv. 104: 315-318.

Van Swaay C.A.M. \& Warren M.S. 1999: Red Data Book of European Butterflies (Rhopalocera). Nature and Environment, No. 99. Council of Europe Publishing, Strasbourg, 260 $\mathrm{pp}$.

VERDU J.R. \& Galante E. (eds) 2006: Libro Rojo de los Invertebrados de España. Dirección General para la Biodiversidad, Ministerio de Medio Ambiente, Madrid, 223 pp.

Vicente J.C. \& HeRnÁndeZ-RoldÁn J.L. 2007: Guía de las Mariposas Diurnas de Castilla y León. Náyade Editorial, Medina del Campo, 280 pp.

WARREN B.C.S. 1926: Monograph of the tribe Hesperiidi (European species) with revised classification of the subfamily Hesperiinae (Paleartic species) based on the genital armature of the males. Trans. Entomol. Soc. Lond. 74: 1-170.

WARREN M.S. 1987: The ecology and conservation of the heath fritillary butterfly, Mellicta athalia. III. Population dynamics and the effect of habitat management. J. Appl. Ecol. 24: 499-513.

WARREN M.S. 1992: Butterfly populations. In Dennis R.L.H (ed.): The Ecology of Butterflies in Britain. Oxford University Press, Oxford, pp. 73-92.

White G.C. \& Burnham K.P. 1999: Program Mark: survival estimation from populations of marked animals. Bird Study 46: $120-113$.

Received December 12, 2008; revised and accepted May 14, 2009 